Kinestetik : Jurnal Ilmiah Pendidikan Jasmani 5 (1) (2021)

Kinestetik : Jurnal Ilmiah Pendidikan Jasmani

https://ejournal.unib.ac.id/index.php/kinestetik/index

DOI : 10.33369/jk.v5i1.14230

\title{
THE PROFILE OF VITAL LUNG CAPACITY ON UJUNG KULON NATIONAL PARK PROFESSIONAL DIVERS
}

\author{
Arief Nuryadin', Ayu Rahayu' ${ }^{2}$, Qory Jumratul 'Aqobah ${ }^{3}$ \\ ${ }^{123}$ Department of Sport Science, Faculty of Medicine, Universitas Sultan Ageng Tirtayasa, \\ Banten, Indonesia
}

\section{Article Info}

Article History :

Received : January 2021

Revised : February 2021

Accepted : March 2021

Available online : March

2021

Keywords:

professional divers, vital lung capacity

\begin{abstract}
This research aims to describe the profile of vital lung capacity of professional divers in Ujung Kulon National Park. This type of research is descriptive with a cross sectional approach. The research subjects in this study is all population of professional divers in Ujung Kulon National Park, totaling 24 people with varying age categories, ranging from 20-29 years, 30-39 years, 40-49 years, to 50-59 years. The data collection techniques in this research were carried out by interviewing, questionnaire, and lung vital capacity tests using spirometer. The data were analyzed by means of descriptive analytic. Based on the results of the spirometry test, it is known that only $12.5 \%$ of professional divers have FVC \%pred, FEV1\% pred and the FEV1 / FVC ratio are in the normal category, two people in the 30-39 year age range, and one person in the age range. $50-59$ years. Another $87.5 \%$ experienced have restriction and obstruction symptoms. The degree of restriction and obstruction disturbance experienced by divers also varies according to age range category.
\end{abstract}

\begin{tabular}{llr}
\hline Corresponding address & : D'mutiara Residence Blok A no.22 & ISSN 2685-6514 (Online) \\
& Sindanglaya, Pandeglang-Prov. Banten & ISSN 2477-331X (Print) \\
*Corresponding email & $:$ arief@untirta.ac.id &
\end{tabular}




\section{INTRODUCTION}

Diving is a sport that has a high risk due to air pressure when the body enters the water, the more the body enters the water, the greater the pressure. Some techniques such as Equalizing are the body's way of balancing it by channeling air from the airways through the Eustachian tubes. Professional divers must be familiar with this technique because besides having to master several diving techniques, they must also have a legally recognized license. A diver has a good vital lung capacity, of course it is very important, because at the time of diving will help a stable endurance. Oxygen $(\mathrm{O} 2)$ intake when the body is doing activities will help so that the muscles do not experience fatigue, this condition is of course very important if divers have good vital lung capacity.

Through the Decree of the Minister of Forestry Number: 284 / KptsII / 1992 dated February 26, 1992, Ujung Kulon was designated as the Ujung Kulon National Park with a total area of 122,956 Ha consisting of land area 78,619 Ha and waters 44,337 $\mathrm{Ha}$. The professional divers of Ujung Kulon National Park have a very important task in preserving the environment, one of which is to carry out underwater conservation, with an area of 44,337 hectares of water and a member of 18 divers under the Department of Maritime Affairs. If divers have good vital lung capacity, it will greatly assist divers in carrying out their duties.

The vital capacity of the lungs can also be said to be the quality of the lungs, to have a good vital lung capacity is to maintain lung function. Maintaining lung function, one of which is doing sports or regular physical activity, diving is an example of getting a good vital lung capacity. Zn, Amin, \& Thufeilsyah (2014) explain that Vital Capacity (VC) is the maximum amount of air that can be exhaled after maximum inspiration: $\mathrm{VC}=$ TV + IRV + ERV (Should be $80 \%$ of TLC). In adult males, the vital capacity of the lungs amounts to about $4800 \mathrm{ml}$.

Spirometry examination is an examination that aims to measure the individual static and dynamic lung volume using a device called a spirometer. Several types of simple electronic spirometer, such as the Spirometer Contect can measure precisely certain parameters related to Vital Capacity (VC), including Forced Vital Capacity (FVC), Forced Expiratory Volume 1 (FEV1), FEV1/ FVC Ratio, and Peak Expiratory Flow (PEF). According to Amin (2013) in Bakhtiar, Irviana, \& Tantri (2017), the spirometer cannot make a specific diagnosis but can determine the presence of obstructive and restrictive disorders and can estimate the degree of abnormality.

Spirometry is a method for screening lung diseases that can also be used in determining chest strength and function, detecting various respiratory diseases, especially due to environmental pollution and cigarette smoke (Herman, 2016).

According to Zn, Amin, \& Thufeilsyah (2014), normal lung function will show the results of $\mathrm{FVC} \%$ pred> $80 \%$, FEV $1 \%$ pred $>80 \%$, and FEV1 / 
FVC> $70 \%$. If the three values are less than these parameters, then lung function can be categorized as having impaired physiological function, either restriction, obstruction, or a combination of restriction-obstruction.

Based on the information obtained by the author, the divers in Ujung Kulon National Park do not yet know what the vital capacity of the lungs is like, with the smoking habit of divers as one of the factors that affect the vital capacity of the lungs to be bad. By using a vital lung capacity measuring instrument, namely Spirometry, the author wants to contribute which is useful for measuring the level of vital lung capacity of professional divers in Ujung Kulon National Park and then a vital lung capacity profile will be created for professional divers that can be used as learning and evaluation of professional divers.

\section{METHODS}

This research is a descriptive study using a cross sectional approach. Descriptive research is a research method that seeks to describe the object or subject under study in accordance with what it is, with the aim of systematically describing the facts and characteristics of the object under study accurately. In this case, descriptive research was carried out to systematically describe the facts and what they are according to the characteristics of the vital lung capacity of professional divers in Ujung Kulon National Park.

\section{Participants}

In this study, the subjects were all 24 professional divers in Ujung Kulon National Park, which was proven by a license or certification of diving expertise whose legality was recognized according to applicable regulations.

\section{Sampling Procedures}

This study uses several data collection techniques, including: 1) Observation, namely by direct observation to the research location to obtain information related to the research problem; 2) Interviews, namely by asking test participants directly with questions that have been prepared in advance in order to obtain actual information regarding the research problem; 3) Questionnaires (adapt by Arikunto, 2010), namely by means of test participants filling in the question posed by researchers who will serve as research respondents and as supporting data; and 4) Spirometry test, which is a test to measure the vital capacity of the lungs for divers. Spirometry test to measure the vital capacity of the lungs with a digital spirometer.

\section{Design or Data Analysis}

The data analysis technique is done by describing the research data that was successfully obtained from data collection, the next step is to analyze and describe the data so that the data can be drawn a conclusion. In this study, the statistical analysis used is a descriptive technique with a percentage to identify, describe and describe the profile of the vital lung capacity of professional divers 
in Ujung Kulon National Park as it is without making generalized conclusions or generalizations (Sugiyono 2015: 207).

\section{RESULT}

Based on the results of the research in table 1 , it can be seen that the majority of TNUK professional divers are in the 30-39 year age category, which is 11 people with a percentage of $46 \%$, while the most are in the 20-29 year age category with a percentage of $4 \%$. The youngest diver is 20 years old while the oldest is 59 years old.

The data in table 2 shows the average FEV1, FVC and FEV1 / FVC ratios based on age categories. The highest average value of FEV1 / FVC ratio is in the 30-39 year age category, which is $81.59 \%$ and the lowest is in the 50-59 year age category, which is $71.57 \%$. The highest predictive value of FEV1\% is in the 30-39 year age category, which is $71.76 \%$ and the lowest is in the 50-59 year age category, which is $55.29 \%$. Meanwhile, the highest predictive value of FVC\% was in the 4049 year age category, namely $81.53 \%$ and the lowest was in the 50-59 year age category, which was $66.19 \%$.

Based on the data in table 2, it can be seen that in all age categories, only the FEV1/ FVC ratio value is in the normal category, while the $\mathrm{FVC} \%$ pred and FEV1\% pred values are below the normal parameter values. This indicates a disruption of pulmonary function in divers. The 20-29 year age category had the highest FEV1 / FVC ratio value, followed by the 30-39 year old category,
40-49 year old category, and the lowest was the 50-59 year age category.

Based on table 3, it is known that only $12.5 \%$ of professional divers have FVC \%pred, FEV1\%pred and the FEV1/ FVC ratio are in the normal category, two people in the 30-39 year age range, and one people in the age range 50-59 years.

The data in Table 4 contain the mean distribution of the $\mathrm{FVC} \%$ pred value, which shows the degree of restriction across all age categories. The data in these tables show that $100 \%$ of divers in the 20-29 year age category experience moderate restriction. In the $30-39$ year age category, $50 \%$ of divers experience moderate restriction and $50 \%$ have moderate-severe restriction. As many as $50 \%$ of divers in the $40-49$ year age category have mild restrictions, while the other $50 \%$ experience moderatesevere restrictions. In the 50-59 year age category, $60 \%$ of divers have moderate restrictions, and $40 \%$ experience severe restrictions.

Furthermore, the data in Table 5 contain the distribution of the mean FEV1\% pred that indicates the degree of obstruction in various age categories. The data in these tables show that $100 \%$ of the divers in the 20-29 year age category have moderate obstruction. In the 30-39 year age category, $44.4 \%$ of divers had mild obstruction, $33.4 \%$ had moderate obstruction, $11.1 \%$ had moderate to severe obstruction, and $11.1 \%$ had severe obstruction. In the 40-49 year age category, $50 \%$ of divers have mild obstruction, and another 50\% have moderate obstruction. Meanwhile, in the 
50-59 year age category, $16.6 \%$ of divers had mild obstruction, $33.4 \%$ had moderate-severe obstruction, and 50\% had severe obstruction.

Based on the data from the results of this study, it is known that the higher a person's age, the lower the FEV1 / FVC ratio value, as shown in table 2 . According to Mawi (in Situmorang, 2014), the increasing age, the average value of FVC drop. Neil \& David (2005) and Syaifuddin (2006) stated that age is one of the factors that influence lung function. The body can experience decreased lung function after the age of 30 years, where each year the surface area of the lungs will be reduced by $4 \%$. Increasing age accompanied by poor environmental conditions and the possibility of suffering from a disease can increase the risk of decreased lung function. This is in line with the data listed in Table 4 regarding the degree of restriction, and Table 5 regarding the degree of obstruction experienced by divers by age category.

In addition, the results of a spirometric examination can also be used in determining chest strength and function, detecting various respiratory diseases, especially due to environmental pollution and cigarette smoke (Herman, 2016). This is evidenced by the results of interviews with the divers which showed that $87.5 \%$ or as many as 21 divers were active smokers.

Table 1. Percentage of TNUK Professional Divers by Age Category

\begin{tabular}{ccc}
\hline $\begin{array}{c}\text { Age } \\
\text { (Year) }\end{array}$ & $\begin{array}{c}\text { Frequency } \\
(\mathbf{n})\end{array}$ & $\begin{array}{c}\text { Percentage } \\
(\boldsymbol{\%})\end{array}$ \\
\hline $\mathbf{2 0 - 2 9}$ & 1 & 4 \\
\hline $\mathbf{3 0 - 3 9}$ & 11 & 46 \\
\hline $\mathbf{4 0 - 4 9}$ & 5 & 21 \\
\hline
\end{tabular}

\begin{tabular}{ccc}
\hline $\mathbf{5 0 - 5 9}$ & 7 & 29 \\
\hline Total & 24 & 100 \\
\hline & Source: Primary data, 2020
\end{tabular}

Table 2. The Average Value of Vital Lung Capacity of TNUK Professional Divers by Age Category

\begin{tabular}{|c|c|c|c|c|c|c|c|}
\hline \multirow[t]{2}{*}{ Age } & \multirow{2}{*}{$\begin{array}{c}\text { FEV1 } \\
\text { (L) }\end{array}$} & \multicolumn{2}{|c|}{ FEV1 } & \multirow{2}{*}{$\begin{array}{c}\text { FVC } \\
\text { (L) }\end{array}$} & \multicolumn{2}{|c|}{ FVC } & \multirow{2}{*}{$\begin{array}{c}\text { FEV } \\
1 / \\
\text { FVC } \\
\%\end{array}$} \\
\hline & & $\begin{array}{c}\text { PRED } \\
\%\end{array}$ & $\begin{array}{c}\text { PRE } \\
\text { D } \\
\text { (L) }\end{array}$ & & $\begin{array}{c}\text { PRED } \\
(\%)\end{array}$ & $\begin{array}{l}\text { PRED } \\
\text { (L) }\end{array}$ & \\
\hline $20-29$ & 2.51 & 63.67 & 3.94 & 3.08 & 66.33 & 4.64 & 81.38 \\
\hline 30-39 & 2.83 & 71.76 & 3.94 & 3.66 & 78.94 & 4.64 & 81.59 \\
\hline $40-49$ & 2.82 & 71.60 & 3.94 & 3.78 & 81.53 & 4.64 & 78.45 \\
\hline $50-59$ & 2.18 & 55.29 & 3.94 & 3.07 & 66.14 & 4.64 & 71.57 \\
\hline
\end{tabular}

Tabel 3. Distribution of Normal Lung Vital Capacity Values (FVC, FEV1, \& FEV1 / FVC Ratio) for Professional TNUK Divers by Age Category

\begin{tabular}{|c|c|c|c|c|c|}
\hline Age & $\begin{array}{c}\text { Value } \\
\% \\
\text { Pred } \\
\text { FVC }\end{array}$ & $\begin{array}{c}\text { Value } \\
\% \\
\text { Pred } \\
\text { FEV1 }\end{array}$ & $\begin{array}{c}\text { Ratio } \\
\text { FEV1/ } \\
\text { FVC }\end{array}$ & $\begin{array}{c}\text { Freque } \\
\text { ncy } \\
\text { (n) }\end{array}$ & $\begin{array}{c}\text { Percentage } \\
(\%)\end{array}$ \\
\hline
\end{tabular}

\begin{tabular}{|c|c|c|c|c|c|}
\hline $\begin{array}{c}20- \\
29\end{array}$ & $>80 \%$ & $>80 \%$ & $>70 \%$ & - & - \\
\hline $\begin{array}{l}\text { 30- } \\
39\end{array}$ & $>80 \%$ & $>80 \%$ & $>70 \%$ & 2 & $66.67 \%$ \\
\hline $\begin{array}{c}40- \\
49\end{array}$ & $>80 \%$ & $>80 \%$ & $>70 \%$ & - & - \\
\hline $\begin{array}{c}50- \\
59\end{array}$ & $>80 \%$ & $>80 \%$ & $>70 \%$ & 1 & $33.33 \%$ \\
\hline \multicolumn{4}{|c|}{ Total } & 3 & $100 \%$ \\
\hline
\end{tabular}

Source: Primary data, 2020

Table 4. Distribution of the\% Pred FVC Value that Shows the Degree of Restriction by Age Category

\begin{tabular}{cccccc}
\hline Restriction & \multicolumn{4}{c}{ Age (year) } & $\begin{array}{c}\text { Frequency } \\
\text { Degree }\end{array}$ \\
\cline { 2 - 5 } & $20-$ & $30-$ & $40-$ & $50-$ & \\
& 29 & 39 & 49 & 59 & \\
\hline Low & - & - & 1 & - & 1 \\
\hline Medium & 1 & 3 & - & 3 & 7 \\
\hline $\begin{array}{c}\text { Medium } \\
\text { High }\end{array}$ & 3 & 1 & - & 4 \\
\hline High & - & - & - & 2 & 2 \\
\hline Very High & - & - & - & - & - \\
\hline Total & 1 & 6 & 2 & 5 & 14 \\
\hline \multicolumn{5}{c}{ Source: Primary data, 2020 }
\end{tabular}




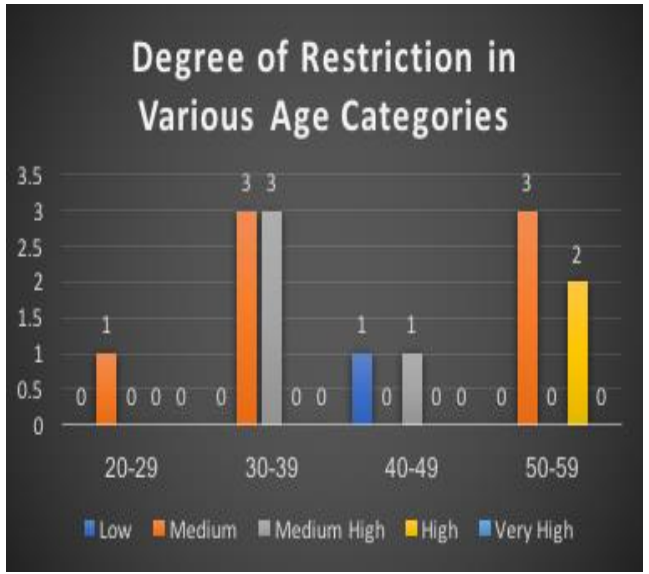

Fig 1. Degree of Restriction in Various Age Categories

Table 5. Distribution of the\% Pred FEV1 Value that Shows the Degree of Obstruction by Age Category

\begin{tabular}{|c|c|c|c|c|c|}
\hline \multirow{2}{*}{$\begin{array}{c}\text { Obstruction } \\
\text { Degree }\end{array}$} & \multicolumn{4}{|c|}{ Age (year) } & \multirow{2}{*}{$\begin{array}{l}\text { Frequency } \\
\text { (n) }\end{array}$} \\
\hline & $\begin{array}{l}20- \\
29\end{array}$ & $\begin{array}{l}30- \\
39\end{array}$ & $\begin{array}{c}40- \\
49\end{array}$ & $\begin{array}{l}50- \\
59\end{array}$ & \\
\hline Low & - & 4 & 2 & 1 & 7 \\
\hline Medium & 1 & 3 & 2 & - & 6 \\
\hline $\begin{array}{l}\text { Medium } \\
\text { High }\end{array}$ & & 1 & - & 2 & 3 \\
\hline High & - & 1 & - & 3 & 4 \\
\hline Very High & - & - & - & - & - \\
\hline Total & 1 & 9 & 4 & 6 & 20 \\
\hline
\end{tabular}

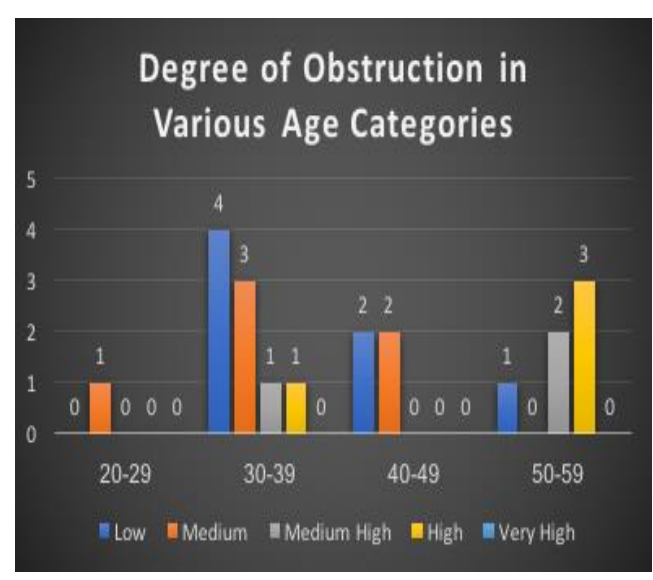

Fig 2. Degree of Obstruction in Various Age Categories

\section{DISCUSSION}

This research needs to be trial on a broader scale by considering several other variables such as length of time diving, physical fitness level, and daily activity patterns of divers, so that the results become more accurate.

\section{CONCLUSION}

The conclusions of the results of this study indicate that based on the results of the spirometry test, it is known that only $12.5 \%$ of professional divers have $\mathrm{FVC} \%$ pred, FEV1\% pred and the FEV1 / FVC ratio are in the normal category, namely two people in the 30-39 year age range, and one person in the 5059 years age range. Another 87.5\% experienced restriction and obstruction symptoms. The results of this study indicate that the higher the age of the diver, the lower the vital capacity of the lungs, both in terms of volume and vital function. In addition, a factor that may affect the decline in lung vitality is the smoking habit of divers. However, to get maximum or more accurate research results, it is necessary to do in-depth research related to this matter.

\section{REFERENCES}

Anna, U., Amin Z., \& Thufeilsyah, F. (2014). Spirometri. Ina J Chest Crit and Emerg Med. Vol. 1 (1), p.35-38.

Arikunto, Suharsimi. (2010). Prosedur Penelitian Suatu pendekatan Praktek. Jakarta: Rineka Cipta.

Bakhtiar, A., Irviana, R. \& Tantri E. (2017). Faal Paru Dinamis. Jurnal Respirasi (JR). Vol 3 (3), p.57-64. 
Caia Francis. (2011). Perawatan Respirasi. Jakarta: Erlangga.

Duke, H.I., Widyastuti, S.R., Suharyo Hadisaputro, S., \& Chasani, S. (2017). Pengaruh Kedalaman Menyelam, Lama Menyelam, Anemia Terhadap Kejadian Penyakit Dekompresi Pada Penyelam Tradisional, Jurnal Kesehatan Masayrakat Indonesia. Vol.12 (2), p.12-18.

Dwipayana, I. M. P., Kusumawati, A. A. I. P., \& Prapti, N. K. G. (2017). Hubungan Aktivitas Menyelam Dengan Kapasitas Vital Paru Pada Penyelam Di Desa Les, Kecamatan Tejakula, Kabupaten Buleleng. Coping (Community of Publishing in Nursing), Vol.5 (1), p.44-55

Kristiningrum, E. \& Isharyadi, F. (2016). Pemenuhan Persyaratan Standar Pengelolaan Wisata Selam Rekreasi. Jurnal Standardisasi Vol.20 (1), p.3348.

Glazer, T. A., \& Telian, S. A. (2016). Otologic Hazards Related to Scuba Diving. Sports Health, Vol.8 (2), p.140-144.

Hadi, N. (2011). Tinjauan Tentang Penyelaman. Jurnal Oseana, Vol.16(4), p.1-12.

Herman, D., Yunus, F., Harahap, F., \& Rasmin, M. (2015). Ambilan Oksigen Maksimal Dan Faal Paru Laki-Laki Sehat Penyelam. Jurnal Respirologi Indonesia, Vol. 31 (2), p.61-71

Juarfianti, Joice N. A. Engka, Siantan Supit. (2015). Kapasitas Vital Paru Pada Penduduk Dataran Tinggi Desa Rurukan Tomohon, Jurnal EBiomedik (Ebm) Vol.3 (1), p.430-434.

Neil, M.R, David D. (2005). Geriatric Medichine. Horisson's Principles of Internal Medicine. Edisi Ke 16. New York: McGraw-Hill Book Company.
Situmorang, B. A., Lintong, F., \& Supit, W. (2014). Perbandingan Forced Vital Capacity Paru Pada Atlet Renang Manado dan Bukan Atlet Renang Di Sulawesi Utara. eBiomedik, 2(2).

Sugiyono. (2015). Metode Penelitian Kuantitatif Kualitatif Dan R\&D.

Bandung: Cv. Alfabeta

Yuma Anugrah. (2014). Faktor-Faktor Yang Berhubungan Dengan Kapasitas Vital Paru Pada Pekerja Penggilingan Divisi Batu Putih Di Pt. Sinar Utama Karya. Unnes journal of public health Vol.3 (1), p.1-9 